\title{
IDEALOGICAL-ARTISTIC CONCERN IN THE CREATION OF KHUSROW DEHLAVI AND ALISHER NAVOI
}

Associate Professor of SamSU, Mukhitdinova Nazmiya.

\begin{abstract}
Annotation
In this article, the role of the traditions of the predecessor Amir Khusrow Dehlavi in the works of Alisher Navoi is illustrated by the artist's uniqueness and the ideological-artistic interpretation of the shared vision of his works. The universal ideals of enlightenment and the question of a perfect human being in the works of the two poets are also emphasized. The ideological and artistic study of the expressions of Amir Khosraw Dehlavi and Alisher Navoi in the spirit of Oriental wisdom on life and man and nature, as well as the magnificent ideas, moral and spiritual ties between them.
\end{abstract}

Keywords: poetry, predecessor, succession, tradition and originality.

\section{Introduction}

One of the most striking and at the same time unique features of literature is that the writers follow their predecessors and create their reply to them. In literary studies, this type of creativity has been called response, "tatabbu", "nazira". Responses to predecessors ranges from great poems to bytes and lines.

This case, concerning to Persian-Tajik and Uzbek literature, does not occur in any neighboring nations or in peoples who live far and speak in two completely different languages. The Tajik (Persian) and Uzbek (Turkic) people have long been familiar with each other's literature, have carefully studied the legacy of the great writers before them, and have been creative followers.

Alisher Navoi's role in the history of Persian-Tajik literature is also important. He headed the Herat Literature School in the fifteenth century, with his mentor and like-minded friend Abdurahman Jomi, and sponsored many Tajik poets, writers, historians, representatives of literary, musicians, artists, and other artists. 


\section{Materials and methods}

In this work, meeting the demands of the theme, the comparative-historical classification methods are used. Scientific source materials form is object.

\section{Expected results and remarks}

Poets of the 15th century applied responses to many their predecessors. Navoi's attention is often drawn to classical writers, including Hakani, Sani, Salman Sovaji, Saadi, Khusrav, Hafiz, Kamal, Jami and others. The special ones are given to Amir Khusrav Delhi. The writings by Alisher Navoi to Amir Khosraw Dehlavi' ghazals are, of course, the result of his outstanding skill.

This is because, of course, the great lyricist's poetry attracted the attention of Alisher Navoi from the point of view of his essence, won his love, and was quite similar. From the point of view of the form, Amir Khosrav Dehlavi's high level ghazals could be a school for young Alisher, and were base to test his craft.

The applications on "Divan" require comparative study. When Alisher Navoi spoke about the period of adherence to poetry in his youth, in the first place, such poets Khodja Hafiz, Khusrav Dehlavi and Jomiye were mentioned as they charmed him and his poetry during this period:

1. As Navoi elevated his native language to art, and though his rivals and opponents accused him of ignorance of Persian, for which he had to strengthen his position in Persian literature.

2. His school, his teachers, and his favorite poets were Khoja Hafiz Sherozi, Amir Khosraw Dehlavi and Abdurahman Jomi.

3. From his youth, he was fascinated by the works of these three poets, learned many of their lyrical ghazals by heart and gave their best "tatabbu"s. In addition, in many ghazels of Navoi, the name of Hafez is mentioned with utmost respect. [2. p. 528]

Navoi mentioned in "Mukhtamatul-lugatayn" that he learned thoroughly the Oriental poetry from fifteen to forty years of age, knew well the works of Hakani, Khusrav Dehlavi, Solmon Savojiy, and Abdurahman Jomiy, learned more than fifty thousand bytes in Persian during his youth, and recorded the answers to many of his great predecessors and contemporaries. 
Navoi wrote that Amir Khosraw Dehlavi highly valued his work "Darioyi abror" and said that "as time passes, all my works will disappear and those who read it will admit that I am a great poet." This is why Navoi responded to Amir Dehlavi's this work. Navoi's contemporary, well-known poet and calligrapher, poet Davlatshah Samani, in his "Tazkiratush-shuaro" just wrote this poem:

In hast javobe na kam az guftayi Xusrav,

Balk-in du suxan xubtar az yak digar uftod.

"Qut ul-qulub" consists of 120 bytes. It is written on mysticism. It describes the world as transitory: kings, also the needies pass away; this world is a desert with no purpose; it is a transient path with no beginning or end.

Navoi strongly criticized religious leaders involved in fraud and corruption under the guise of religion:

Piyolahoyi puropur xo'ry, zi nomardy,

$\mathrm{V}$-az on ba xotiri tu dam ba dam xayoli zinost.

Chu on-t gasht muyassar na karda g'usl hanuz,

Miyoni xalq ba da'voyi mardiyat g'avg'ost.

Ajabtar on, ki zanatro ba mardake chun tu

Hamin muamola raftast, xud haminat sazost.

Dilat, ki hayli shayotinu devro vatan ast...

Zi matni botini shumat hama halok shavand.

Chunon, ki go'yyo on xaylro fitoda vabost. [1 pp. 238-239]

The ode "Minhoj un-najot" consists of 138 bytes. It was written in response to the odes of Hakani and Anwori.

The ode "Nasim al-khuld" is about 129 bytes. It was written in response to the Hakani's odes. This work is also as much a mystic as the one in " Minhaj un-najot".

Navoi asks not to belive in worshipers, who pray hundreds times, deceptive sheikhs, and advice and admonitions of dumb preachers:

Turo sad bahri toat gar buvad, lekin riyoolud,

Chi go'y bahri toat beh, ki go'yi bahri isyonash.

Ba tarki zarq shayxi hiylagarro nest chuz nuqson, 
Chy yobad sud bozore, ki shud barbasta do'konash.

Ba pandi voizi g'ofil mayafgan go'shu z-on bigzar,

Ki dar xob ast az g'aflat hamon afsona hazyonash. [1 pp. 273-274]

At the end of the ode, the idea of ruling the country as a dervish was implied. Sultan Hussain Baikarah was praised as a dervish, a king of poverty:

Shahi darveshvash, sultoni faqroin, ki az-Ezad

Farozi taxti shohi faqru darvesh ast dar shonash. [1 C. 274]

Navoi proudly remembered Khosraw Dehlavi, Abdurahman Jomi and Hakani in the ode and noted that he continued the way they had started.

Navoi called on to act the Koran, the Shari'a principles of the Prophet Muhammad, to live a righteous, and modest life in the odes of "Sittayi zaruriya". He opposes the poor life to the world of injustice, oppression, and ignorance ("Faqru fano", "Nasibsoz tariqi fano, ki ayni baqost "). The spirit of "Nakshbandiya" was deeply engrained in his Persian works.

The odes were written with high art and artistic skill. They were decorated with a variety of artistic tools and colorful drawings taken from life.

\section{Summary}

Consequently, Alisher Navoi's attitude towards Khosraw Dehlavi's poems was found not only in his ghazals but also in the poems of "Tuhfat ul-afkor's", which was written in response to the ode "Daryoyi abror". He took some of his character traces of his predecessor and used them in his own odes. However, he used such lines in a completely new sense, in new stylistic ways, and as a result, the content of the verses resonated more strongly, and they were so intertwined with the overall spirit and structure of the body that it is impossible to notice that they belong to Khosraw. For example:

Lozimi shohy naboshad xoly az dardi sare, «Ko'si shah xoliyu bongi g'ulg'ulash dardi sar ast».

Bo dahoni xushku chashmi tar qanoat kun, az on-k «Har ki qone’ shud ba xushku tar shahi bahru bar ast». [1. p.205] 
The publishers did not notice the second of these bytes that they belong to Khosraw. Therefore, no proper punctuation was given. It indicates not just a joint according to form, but also a joint with meaning.

This explains the mystery of the origins of the "tatabbu"s taken from "Devoni Foni" and the reason why these poets became more followers.

In the poetry of Amir Khosraw Dehlavi and Alisher Navoi, the similarity of the issue of the perfect man was also reflected in this point.

Alisher Navoi, who came to the literary field with his brilliant talent and enlightened thinking, was an avid student of the representatives of early Persian and Turkic literature, and sincerely adhered to them, followed by them and inspired.

The creative work of Amir Khosraw Dehlavi, who had a special epoch in the history of Persian-language literature, was fascinated by Alisher Navoi's first and foremost art, which was a masterpiece of " haqiqat asrorig'a majoz tariqini maxlut ". Perhaps this is why Alisher Navoi respected Amir Khosraw's creativity and personality and described him as "the head and leader of the people of love and affliction" and "the luminous archetype of the ceasefire and the representative of the room of pain."

The greatness and creativity of these two genius artists and their precious literary heritage and living ideas are still alive today, first and foremost, despite many centuries and many representatives in life and literature, also its importance was not diminished. After all, these immaculate writings of the pious perfectionists and the masterpieces of the world of "word", which reached the spiritual heights of the perfection of Islamic enlightenment, were not only works of art, but also good calls to humanity.

It is not difficult to see the ideological proximity, the national and logical basis of the expression of ideas, and it would be very simple to consider this as merely an external similarity or common ground. However, this understanding was primarily a reflection of Amir Khosraw Dehlavi and Alisher Navoi's vision of Oriental wisdom on life and man and nature, as well as the magnificent ideals and moral-spiritual ties between the two great artists. Secondly, it is also worth noting that this ideological 
collaboration was a firm judgment of the two great artists, that is, a profound philosophical observation of the wretched and inferior ones.

It is also worth noting that in the works of both poets it was a great honor to display such virtues as justice and enlightenment, kindness and generosity directly on the basis of life examples, and on the contrary, to expose brutally such wrongs as dishonesty and extortion, ignorance and neglect.

It is clear that such ideological proximity and harmony in the works of Amir Khosrav Dehlavi and Alisher Navoi was an important area of their creativity and world of thought.

Navoi and Amir Khosraw Dehlavi's creative works were undoubtedly the most important part of the chain of artistic spiritual ties that had been emerged on the basis of deep thinking and life lessons, immortal ideas and high universal values among people of different generations.

\section{The list of used literature:}

1. Alisher Navoi. Volume 20. Devoni Foni. - T .: Science, 2003.

2. Alisher Navoi. TAT. 10 volumes. Volume X. Mukhokamat ul-lughatayn. Tashkent. Gafur Gulom Publishing House, 2011.

3. Valikhojaev B., Vokhidov R. Navoi is a source of inspiration. - T., 1981.

4. Dehlavi A.H .. Muntahabot. «Irfon». - Dushanbe, 1975.

5. Dehlavi A.Kh.. Works. Fiction Publishing House named after Gafur Gulom. Tashkent, 1972.

6. Isxakov Y. Navoi and Khosraw Dehlavi // Navoi and the problems of Literary Influence. - Tashkent, 1968. 